\title{
Financial Performance Appraisal of Selected Companies in Jordan
}

\author{
Basman Al Dalayeen \\ Faculty of Business Administration and Economics, Al-Hussein Bin Talal University, Ma'an, Jordan \\ Email: basman_2014@yahoo.com
}

How to cite this paper: Al Dalayeen, B. (2017) Financial Performance Appraisal of Selected Companies in Jordan. Open Journal of Business and Management, 5, 131140.

http://dx.doi.org/10.4236/ojbm.2017.51012

Received: November 9, 2016

Accepted: December 27, 2016

Published: December 30, 2016

Copyright $\odot 2017$ by author and Scientific Research Publishing Inc. This work is licensed under the Creative Commons Attribution International License (CC BY 4.0). http://creativecommons.org/licenses/by/4.0/

\begin{abstract}
The financial performance of an organization is influenced by several factors like capital structure, cost, revenue and the consequential profit margin. The best indicators of the financial performance are return on assets, sales, equity and other financial variables. In this study, the researcher has analyzed the performance of selected companies in Jordan on the parameters such as profitability, utilization of assets, growth of performance, financial strength and capital structure. The researcher has also attempted to identify the nature of relationship between the various aspects of financial performance.
\end{abstract}

\section{Keywords}

Performance, Companies, Ratios, Sales, Equity

\section{Introduction}

The term performance refers to the act of performing, execution, accomplishment, fulfillment of a given task measured against preset standards of accuracy, completeness, cost, and speed [1]. Performance indicates how the management of an enterprise has been accomplishing the goals, which they had set for the enterprise [2]. Performance is a measure of the degree to which an organization fulfills its purpose and the purpose is to achieve its objectives [3]. So far financial performance is concerned, it is the evaluation and interpretation of a firm's financial positions and operations and involves a comparison and interpretation of accounting data [4]. The purpose of financial analysis is to diagnose the information contained in financial statements so as to judge the profitability and financial soundness of the firm just like a doctor examines his patient by recording his body temperature, or blood pressure, etc. [5]. Nevertheless, a financial analyst analyzes the financial statements before commenting upon the financial heath or weaknesses of an enterprise. Financial performance analysis is the analysis of financial statements, like balance sheet and profit and loss account aimed at diagnosing the 
profitability and financial condition of a business concern [6]. It is a scientific tool which played an important role in terms of appraising the real worth of an enterprise. It helps in drawing out the complications of what is contained in the financial statements [7]. Therefore, in the present research, the term financial performance is concerned with the analysis of financial statements only and the tool used to measure the financial performance of the companies is financial ratios. The main purpose of this analysis is to evaluate past performance, financial position, liquidity position, future prospects for earnings, ability to pay interest and debt on maturity and profitability of Indian automobile companies.

\section{Literature Review}

Working Capital Management (WCM) plays an important role in creating value for the shareholders. The way working capital was managed had a significant impact on both profitability and liquidity. It was found that there is negative relationship between lengths of the firm's net trading cycle and its profitability [8]. Efficient liquidity management involves planning and controlling current assets and current liabilities in such a manner that eliminates the risk of inability to meet due short-term obligations and avoids excessive investment in these assets [9]. The relation between profitability and liquidity was validated, as measured by current ratio and cash gap (cash conversion cycle) on a sample of joint stock companies in Saudi Arabia using correlation and regression analysis. The study concluded that the cash conversion cycle is having more importance as a measure of liquidity than the current ratio that affects profitability. The size variable was found to have significant effect on profitability at the industry level [10]. The study by Debasish (2006) measured the performance of Indian banks over the period 1997-2004. The author has used the output-oriented CRR, DEA model. The analysis used nine input variables and seven output variables. The analysis supports the conclusion that foreign owned banks were on average most efficient and that new banks were more efficient that old ones, which were often burdened with old debts. In terms of size, the smaller banks are globally efficient, but large banks are locally efficient. Moreover, the study finds out the evidence of efficiency parameters among peer bank groups [11]. The importance of efficient working capital management is indisputable in paper industry as it has a direct impact on EBIT and liquidity [12]. The research by Napompech (2012) showed negative relationship between the gross operating profits and inventory conversion period and receivable collection period, and also validated the essential role of working capital management in value creation of firms by shortening the cash conversion cycle [13]. Besides, the impact of working capital and its management with the profitability of company have been measured by taken seven proxy variables. The data were related with the manufacturing sector of Pakistan listed on Karachi stock exchange. Their study showed that working capital has significant relationship with firm's profitability and firm size has also significant relation with firm profitability [14].

\section{Objectives of the Study}

The following are the broad objectives of the study: 
1) To provide an introductory background of the selected companies in Jordan.

2) To study the profitability position of the selected companies in Jordan.

3) To analyze the impact of financial ratios on the profitability of the selected companies in Jordan.

\section{Hypotheses of the Study}

Ho1: There is no significant impact of financial ratios on the financial performance of Arab East Real Estate Investments Company.

Ha1: There is a significant impact of financial ratios on the financial performance of Arab East Real Estate Investments Company.

Ho2: There is no significant impact of financial ratios on the financial performance of Specialized Jordanian Investment.

$\mathrm{Ha} 2$ : There is a significant impact of financial ratios on the financial performance of Specialized Jordanian Investment.

Ho3: There is no significant impact of financial ratios on the financial performance of Al-Bilad Medical Services.

Ha3: There is a significant impact of financial ratios on the financial performance of Al-Bilad Medical Services.

Ho4: There is no significant impact of financial ratios on the financial performance of Jordan Electric Power.

Ha4: There is a significant impact of financial ratios on the financial performance of Jordan Electric Power.

Ho5: There is no significant impact of financial ratios on the financial performance of Jordan National Shipping Lines.

Ha5: There is a significant impact of financial ratios on the financial performance of Jordan National Shipping Lines.

\section{Research Methodology}

The study is based on the secondary sources of data collected from the published annual reports of the selected companies of the past thirteen years i.e. 2001-02 to 2013-14. Besides, the data has been collected from the articles published in various business newspapers, journals, and internet. Multiple Regression has been used to analyze the impact of financial ratios on the financial performance of the selected companies.

\subsection{Scope of the Study}

The present study highlights the financial performance of selected companies in Jordan through facts of published financial data. The financial performance of all these companies has been evaluated on the parameters like profitability, utilization of assets, growth of performance, financial strength and financial health.

\subsection{Limitations of the Study}

The reliability of the study depends on the accuracy of data collected. The present study is based on the published secondary data and hence the limitations of the published financial statement limitations may be applicable to this study. 


\subsection{Companies Selected in the Study}

Following companies have been selected for analysis in this study:

1. Arab East For Real Estate Investments Company

2. Specialized Jordanian Investment

3. Al-Bilad Medical Services

4. Jordan National Shipping Lines

5. Jordan Electric Power

\section{Multiple Regression Model}

To study the impact of financial ratios on the financial performance of the selected companies in Jordan, the multiple regression model has been used. The fitted model is shown here;

$$
Y=\beta_{0}+\beta_{1} X_{1}+\beta_{2} X_{2}+\beta_{3} X_{3}+\beta_{4} X_{4}+\beta_{5} X_{5}+\beta_{6} X_{6}+\beta_{7} X_{7}+\beta_{8} X_{8}+U
$$

where;

$Y$-Net Profit/Return on Equity

$X_{1}=$ Current Ratio

$X_{2}=$ Quick Ratio

$X_{3}=$ Current Assets to Total Assets Ratio

$X_{4}=$ Inventory Turnover Ratio

$X 5=$ Debtors Turnover Ratio

$X 6=$ Working Capital Ratio

$X 7=$ Total Assets Turnover Ratio

$X 8=$ Fixed Assets Turnover Ratio

$b_{1}, b_{2}, \ldots b_{8}-$ Regression coefficients of predictor variables.

$U=$ disturbance term and

$A$-Intercept

\section{Hypotheses Testing}

Hypothesis 1

Ho1: There is no significant impact of financial ratios on the financial performance of Arab East Real Estate Investments Company.

Hal: There is a significant impact of financial ratios on the financial performance of Arab East Real Estate Investments Company.

Multiple linear regression used to find out the impact of financial ratios on the financial performance of Arab East Real Estate Investments Company. The null hypothesis states that the there is no significant impact of financial ratios on the financial performance of Arab East Real Estate Investments Company and the alternate states that there is a significant impact of financial ratios on the financial performance of Arab East Real Estate Investments Company.

Table 1 shows the results of multiple linear regression used to find out the impact of financial ratios on the financial performance of Arab East for Real Estate Investments company. The current ratio, quick ratio, operating ratio, inventory and debtors' turnover ratios, debt equity ratio are positively influenced the Return on Sales (ROS) as well as Return on equity (ROE). The value of adjusted R square is 0.897 which means that 
Table 1. Multiple linear regression model of Arab east real estate investments.

\begin{tabular}{ccccccc}
\hline Model-1 & \multicolumn{7}{c}{ Dependent Variables } \\
\hline \multirow{2}{*}{ Independent Variables } & \multicolumn{3}{c}{ Return on Sales } & \multicolumn{4}{c}{ Return on Equity } \\
\cline { 2 - 7 } & $\begin{array}{c}\text { Regression } \\
\text { Coefficients }\end{array}$ & $t$ Value & $P$ Value & $\begin{array}{c}\text { Regression } \\
\text { Coefficients }\end{array}$ & $t$ Value & $P$ Value \\
\hline (Constant) & 44.451 & 37.561 & 0.474 & 21.261 & 11.443 & 0.078 \\
Current Ratio & 2.412 & 19.471 & 0.000 & 1.478 & 4.571 & 0.001 \\
Quick Ratio & 1.784 & -23.451 & 0.001 & 1.577 & 2.469 & 0.000 \\
Operating Ratio & 1.990 & -4.745 & 0.000 & 2.014 & 10.412 & 0.000 \\
Inventory Turnover Ratio & 2.413 & 31.033 & 0.000 & 2.337 & 16.574 & 0.000 \\
Debtors Turnover Ratio & 1.986 & 14.704 & 0.007 & 1.674 & 5.577 & 0.001 \\
Debt Equity Ratio & 1.775 & 13.241 & 0.002 & 1.493 & 21.303 & 0.004 \\
Adjusted R & & 0.897 & & & 0.799 & \\
\hline
\end{tabular}

89.7\% variation in return on sales (ROS) is explained by independent variables while rest of the variation is an unexplained variation that is due to other variables that has not been considered in this model. So far as return on equity (ROE) is concerned, the value of adjusted $\mathrm{R}$ square is 0.799 which means that $79.9 \%$ variation in return on equity (ROE) is explained by independent variables while rest of the variation is an unexplained variation. The significant value for each variable is less than 0.005 . Therefore, null hypothesis stands rejected and it can be said that there is a significant impact of financial ratios on the financial performance of Arab East Real Estate Investments Company.

\section{Hypothesis 2}

Ho2: There is no significant impact of financial ratios on the financial performance of Specialized Jordanian Investment.

Ha2: There is a significant impact of financial ratios on the financial performance of Specialized Jordanian Investment.

Multiple linear regression used to find out the impact of financial ratios on the financial performance of Specialized Jordanian Investment. The null hypothesis states that the there is no significant impact of financial ratios on the financial performance of Specialized Jordanian Investment and the alternate states that there is a significant impact of financial ratios on the financial performance of Specialized Jordanian Investment.

Table 2 shows the results of multiple linear regression used to find out the impact of financial ratios on the financial performance of Arab East for Real Estate Investments company. The current ratio, quick ratio, operating ratio, inventory and debtors' turnover ratios, debt equity ratio are positively influenced the Return on Sales (ROS) as well as Return on equity (ROE). The value of adjusted $\mathrm{R}$ square is 0.665 which means that $66.5 \%$ variation in return on sales (ROS) is explained by independent variables while rest of the variation is an unexplained variation that is due to other variables that has not been considered in this model. So far as return on equity (ROE) is concerned, the value of adjusted $\mathrm{R}$ square is 0.587 which means that $58.7 \%$ variation in return on eq- 
Table 2. Multiple linear regression model of specialized Jordanian investment.

\begin{tabular}{ccccccc}
\hline Model-2 & \multicolumn{7}{c}{ Dependent Variables } \\
\hline \multirow{2}{*}{ Independent Variables } & \multicolumn{3}{c}{ Return on Sales } & \multicolumn{4}{c}{ Return on Equity } \\
\cline { 2 - 7 } & $\begin{array}{c}\text { Regression } \\
\text { Coefficients }\end{array}$ & $t$ Value & $\boldsymbol{P}$ Value & $\begin{array}{c}\text { Regression } \\
\text { Coefficients }\end{array}$ & $\boldsymbol{t}$ Value & $\boldsymbol{P}$ Value \\
\hline (Constant) & 33.048 & 37.561 & 0.879 & 19.887 & 11.443 & 0.338 \\
Current Ratio & 2.007 & 4.874 & 0.000 & 1.668 & 31.033 & 0.001 \\
Quick Ratio & 1.593 & 3.340 & 0.000 & 1.087 & 14.704 & 0.009 \\
Operating Ratio & 2.014 & 17.761 & 0.000 & 2.334 & 10.412 & 0.008 \\
Inventory Turnover Ratio & 2.339 & 21.223 & 0.000 & 1.996 & 16.574 & 0.000 \\
Debtors Turnover Ratio & 2.247 & 1.078 & 0.000 & 1.831 & 5.577 & 0.000 \\
Debt Equity Ratio & 1.863 & 16.241 & 0.000 & 1.776 & 4.229 & 0.000 \\
Adjusted R $\mathrm{R}^{2}$ & & 0.665 & & & 0.587 & \\
\hline
\end{tabular}

uity (ROE) is explained by independent variables while rest of the variation is an unexplained variation. The significant value for each variable is less than 0.005 . Therefore, null hypothesis stands rejected and it can be said that there is a significant impact of financial ratios on the financial performance of Specialized Jordanian Investment.

Hypothesis 3

Ho3: There is no significant impact of financial ratios on the financial performance of Al-Bilad Medical Services.

Ha3: There is a significant impact of financial ratios on the financial performance of Al-Bilad Medical Services.

Multiple linear regression used to find out the impact of financial ratios on the financial performance of Al-Bilad Medical Services. The null hypothesis states that the there is no significant impact of financial ratios on the financial performance of Al-Bilad Medical Services and the alternate states that there is a significant impact of financial ratios on the financial performance of Al-Bilad Medical Services.

Table 3 shows the results of multiple linear regression used to find out the impact of financial ratios on the financial performance of Al-Bilad Medical Services. The current ratio, quick ratio, operating ratio, inventory and debtors' turnover ratios, debt equity ratio are positively influenced the Return on Sales (ROS) as well as Return on equity (ROE). The value of adjusted $\mathrm{R}$ square is 0.693 which means that $69.3 \%$ variation in return on sales (ROS) is explained by independent variables while rest of the variation is an unexplained variation that is due to other variables that has not been considered in this model. So far as return on equity (ROE) is concerned, the value of adjusted $\mathrm{R}$ square is 0.707 which means that $70.7 \%$ variation in return on equity (ROE) is explained by independent variables while rest of the variation is an unexplained variation. The significant value for each variable is less than 0.005 . Therefore, null hypothesis stands rejected and it can be said that there is a significant impact of financial ratios on the financial performance of Al-Bilad Medical Services.

Hypothesis 4

Ho4: There is no significant impact of financial ratios on the financial performance of Jordan Electric Power. 
Table 3. Multiple linear regression model of Al-Bilad medical services.

\begin{tabular}{ccccccc}
\hline Model-3 & \multicolumn{7}{c}{ Dependent Variables } \\
\hline \multirow{2}{*}{ Independent Variables } & \multicolumn{3}{c}{ Return on Sales } & \multicolumn{3}{c}{ Return on Equity } \\
\cline { 2 - 7 } & $\begin{array}{c}\text { Regression } \\
\text { Coefficients }\end{array}$ & $t$ Value & $\boldsymbol{P}$ Value & $\begin{array}{c}\text { Regression } \\
\text { Coefficients }\end{array}$ & $\boldsymbol{t}$ Value & $P$ Value \\
\hline (Constant) & 61.542 & 37.561 & 0.909 & 19.887 & 55.443 & 0.557 \\
Current Ratio & 2.447 & 14.874 & 0.001 & 2.287 & 11.033 & 0.000 \\
Quick Ratio & 1.243 & 13.240 & 0.000 & 2.134 & 4.764 & 0.001 \\
Operating Ratio & 2.664 & 7.461 & 0.0061 & 1.997 & 2.412 & 0.000 \\
Inventory Turnover Ratio & 2.109 & 2.443 & 0.000 & 2.007 & 16.574 & 0.000 \\
Debtors Turnover Ratio & 2.771 & 11.878 & 0.0044 & 2.365 & 15.477 & 0.0023 \\
Debt Equity Ratio & 1.443 & 41.201 & 0.000 & 1.446 & 14.019 & 0.001 \\
Adjusted R & & 0.693 & & & 0.707 & \\
\hline
\end{tabular}

Ha4: There is a significant impact of financial ratios on the financial performance of Jordan Electric Power.

Multiple linear regression used to find out the impact of financial ratios on the financial performance of Jordan Electric Power. The null hypothesis states that the there is no significant impact of financial ratios on the financial performance of Jordan Electric Power and the alternate states that there is a significant impact of financial ratios on the financial performance of Jordan Electric Power.

Table 4 shows the results of multiple linear regression used to find out the impact of financial ratios on the financial performance of Jordan Electric Power. The current ratio, quick ratio, operating ratio, inventory and debtors' turnover ratios, debt equity ratio are positively influenced the Return on Sales (ROS) as well as Return on equity (ROE). The value of adjusted $\mathrm{R}$ square is 0.655 which means that $65.5 \%$ variation in return on sales (ROS) is explained by independent variables while rest of the variation is an unexplained variation that is due to other variables that has not been considered in this model. So far as return on equity (ROE) is concerned, the value of adjusted $\mathrm{R}$ square is 0.724 which means that $72.4 \%$ variation in return on equity (ROE) is explained by independent variables while rest of the variation is an unexplained variation. The significant value for each variable is less than 0.005 . Therefore, null hypothesis stands rejected and it can be said that there is a significant impact of financial ratios on the financial performance of Jordan Electric Power.

Hypothesis 5

Ho5: There is no significant impact of financial ratios on the financial performance of Jordan National Shipping Lines.

Ha5: There is a significant impact of financial ratios on the financial performance of Jordan National Shipping Lines.

Multiple linear regression used to find out the impact of financial ratios on the financial performance of Jordan National Shipping Lines. The null hypothesis states that the there is no significant impact of financial ratios on the financial performance of Jordan National Shipping Lines and the alternate states that there is a significant impact of financial ratios on the financial performance of Jordan National Shipping Lines. 
Table 5 shows the results of multiple linear regression used to find out the impact of financial ratios on the financial performance of Jordan National Shipping Lines. The current ratio, quick ratio, operating ratio, inventory and debtors' turnover ratios, debt equity ratio are positively influenced the Return on Sales (ROS) as well as Return on equity (ROE). The value of adjusted $\mathrm{R}$ square is 0.539 which means that $53.9 \%$ variation in return on sales (ROS) is explained by independent variables while rest of the variation is an unexplained variation that is due to other variables that has not been considered in this model. As far as return on equity (ROE) is concerned, the value of adjusted $R$ square is 0.595 which means that $59.5 \%$ variation in return on equity (ROE) is explained by independent variables while rest of the variation is an unexplained variation. The significant value for each variable is less than 0.005 . Therefore, null hypothesis stands rejected and it can be said that there is a significant impact of financial ratios on the financial performance of Jordan National Shipping Lines.

Table 4. Multiple linear regression model of Jordan electric power.

\begin{tabular}{|c|c|c|c|c|c|c|}
\hline \multirow[b]{3}{*}{ Independent Variables } & \multicolumn{6}{|c|}{ Dependent Variables } \\
\hline & \multicolumn{3}{|c|}{ Return on Sales } & \multicolumn{3}{|c|}{ Return on Equity } \\
\hline & $\begin{array}{l}\text { Regression } \\
\text { Coefficients }\end{array}$ & $t$ Value & $P$ Value & $\begin{array}{l}\text { Regression } \\
\text { Coefficients }\end{array}$ & $t$ Value & $P$ Value \\
\hline (Constant) & 65.442 & 17.461 & 0.837 & 19.887 & 55.443 & 0.445 \\
\hline Current Ratio & 2.447 & 15.477 & 0.000 & 2.287 & 2.446 & 0.000 \\
\hline Quick Ratio & 1.243 & 14.019 & 0.000 & 2.664 & 14.874 & 0.000 \\
\hline Operating Ratio & 2.365 & 11.556 & 0.000 & 2.109 & 13.240 & 0.000 \\
\hline Inventory Turnover Ratio & 1.446 & 12.443 & 0.000 & 2.771 & 7.461 & 0.000 \\
\hline Debtors Turnover Ratio & 2.227 & 11.878 & 0.000 & 2.009 & 5.449 & 0.000 \\
\hline Debt Equity Ratio & 1.443 & 41.201 & 0.000 & 2.374 & 17.229 & 0.000 \\
\hline Adjusted $\mathrm{R}^{2}$ & \multicolumn{3}{|c|}{0.655} & \multicolumn{3}{|c|}{0.724} \\
\hline
\end{tabular}

Table 5. Multiple linear regression model of Jordan national shipping lines.

\begin{tabular}{|c|c|c|c|c|c|c|}
\hline \multirow[b]{3}{*}{ Independent Variables } & \multicolumn{6}{|c|}{ Dependent Variables } \\
\hline & \multicolumn{3}{|c|}{ Return on Sales } & \multicolumn{3}{|c|}{ Return on Equity } \\
\hline & $\begin{array}{l}\text { Regression } \\
\text { Coefficients }\end{array}$ & $t$ Value & $P$ Value & $\begin{array}{l}\text { Regression } \\
\text { Coefficients }\end{array}$ & $t$ Value & $P$ Value \\
\hline (Constant) & 92.742 & 17.461 & 0.758 & 19.887 & 43.228 & 0.669 \\
\hline Current Ratio & 2.447 & 22.477 & 0.000 & 2.287 & 14.019 & 0.000 \\
\hline Quick Ratio & 1.009 & 7.461 & 0.002 & 1.664 & 11.556 & 0.000 \\
\hline Operating Ratio & 2.465 & 5.449 & 0.000 & 2.269 & 12.443 & 0.000 \\
\hline Inventory Turnover Ratio & 1.446 & 17.229 & 0.000 & 2.771 & 9.907 & 0.001 \\
\hline Debtors Turnover Ratio & 2.118 & 16.661 & 0.0066 & 2.449 & 12.228 & 0.000 \\
\hline Debt Equity Ratio & 1.229 & 13.338 & 0.000 & 1.374 & 34.449 & 0.0033 \\
\hline Adjusted $\mathrm{R}^{2}$ & & 0.539 & & & 0.595 & \\
\hline
\end{tabular}




\section{Conclusion}

Financial performance is the evaluation and interpretation of a firm's financial positions and operations and involves a comparison and interpretation of accounting data. Financial performance analysis is the analysis of financial statements, like balance sheet and profit and loss account aimed at diagnosing the profitability and financial condition of a business concern. It is a scientific tool which played an important role in terms of appraising the real worth of an enterprise. It helps in drawing out the complications of what is contained in the financial statements. In the present research, financial performance is measured with the help of financial ratios. Current ratio, quick ratio, operating ratio, inventory turnover ratios, debtors' turnover ratios, debt equity ratios, return on sales (ROS), and return on equity (ROE) have been calculated, and thereafter multiple linear regression has been applied to find out the impact of these financial ratios on the financial performance of selected companies in Jordan. The analysis of the data shows that there is a significant impact of financial ratios on the financial performance of Arab East for Real Estate Investments Company, Al-Bilad Medical Services, Jordan Electric Power, and Jordan National Shipping Lines.

\section{References}

[1] Abdullah, P.K. and Ahmad, A. (2014) Financial Performance Appraisal of Selected Investments Companies in Jordan. Jordan Journal of Economic Sciences, 14, 28-35.

[2] Bernstein, LA. and Wild, J.J. (2004) Analysis of Financial Statements. Tata Mcgraw Hill Publishing Co. Ltd., New Delhi, 111-150.

[3] Debasish, S.S. (2006) Efficiency Performance in Indian Banking-Use of Data Envelopment Analysis. Global Business Review, 7, 325-333. https://doi.org/10.1177/097215090600700209

[4] Eljelly, A.M. (2004) Liquidity-Profitability Tradeoff: An Empirical Investigation in an Emerging Market. International Journal of Commerce and Management, 14, 48-61. https://doi.org/10.1108/10569210480000179

[5] Khan, M.Y. and Jain, P.K. (2005) Financial Management-Text, Problems, and Cases. Tata McGraw Hill Publishing Co. Ltd., New Delhi, 7.1-7.66.

[6] Khalid, A.S. and Waleed, J.T. (2013) A Study on Performance Appraisal of Insurance Companies in Jordan with Special Reference to Middle East Insurance and Jordan Insurance. Dirasat. Human and Social Sciences, 18, 36-41.

[7] Napompech, K. (2012) Effects of Working Capital Management on the Profitability of Thai Listed Firms. International Journal of Trade, Economics and Finance, 3, 227-232. https://doi.org/10.7763/IJTEF.2012.V3.205

[8] Nasir, S.I.S. and Iqbal, N. (2015) Working Capital Management Antecedants Impact on Firm Specific Factors: A Ten Year Review of Karachi Stock Exchange. Journal of Poverty, Investment and Development, 13, 141-144.

[9] Pandey, I.M. (2004) Financial Management. Vikas Publishing House Pvt. Ltd., New Delhi, 517-540.

[10] Rehman, M.U. and Anjum, N. (2013) Determination of the Impact of Working Capital Management on Profitability: An Empirical Study from the Cement Sector in Pakistan. Asian Economic and Financial Review, 3, 319-332.

[11] Shin, H.H. and Soenen, L. (1998) Efficiency of Working Capital Management and Corporate Profitability. Financial Practice and Education, 8, 37-45.

[12] Salman, A.N.K. and Abdulaziz, M.K. (2014) An Empirical Study on the Financial Sound- 
ness of Jordan Hotels and Tourism. American Journal of Trade and Policy, 1, 91-95.

[13] Shahnawaz, M.F. and Fahd, T. (2015) Evaluation of Financial Performance of Jordan Express Tourist Transport. Jordan Journal of Business Administration, 55, 154-159.

[14] Zhang, Y. (2009) Performance Appraisal for Chinese State-Owned Banking Industry. International Journal of Applied Research, 6, 189-200. https://doi.org/10.1386/jots.6.3.189/1

Submit or recommend next manuscript to SCIRP and we will provide best service for you:

Accepting pre-submission inquiries through Email, Facebook, LinkedIn, Twitter, etc. A wide selection of journals (inclusive of 9 subjects, more than 200 journals)

Providing 24-hour high-quality service

User-friendly online submission system

Fair and swift peer-review system

Efficient typesetting and proofreading procedure

Display of the result of downloads and visits, as well as the number of cited articles Maximum dissemination of your research work

Submit your manuscript at: http://papersubmission.scirp.org/

Or contact ojbm@scirp.org 